\title{
THE GENERAL CONFEDERATION OF THE GRAND DUCHY OF LITHUANIA
}

(1734-1736)

\author{
Feliksas Sliesoriūnas
}

ABSTRACT This article deals with the issue of the political alliance of the nobility of the Grand Duchy of Lithuania (GDL) - the activity of the General Confederation of the GDL between 1734 and 1736 focusing on issues which have not been researched properly up to now.

The General Confederation of the Polish Kingdom, called the Confederation of Dzików was politically akin to that of the GDL. The Poles proposed to form a common confederation, but the Lithuanian leadership was not inclined to do that. The General Confederation of the GDL established in 1734 was the last such organization of Lithuanian nobles, which did not join the Polish General Confederation. Nevertheless, in emigration the two confederations maintained close contacts. The internal conflicts of 1733-1736 came to an end following the Pacification Sejm in June and July 1736, which granted an amnesty to the Confederates and confirmed the election of Augustus III.

Drawing on the so far untapped archival sources, the author reveals the contemporary diplomatic and military activity of Russia.

Augustus II's death in 1733 ushered in an interregnum in Poland-Lithuania, called the Commonwealth of the Two Nations. That period was characterized by the struggle between the adherents of Stanislaus Leszczyński and Frederick Augustus (Wettin) of Saxony, the son of the deceased king. On 12 September 1733 around 13,000 nobles elected Leszczyński as King Stanislaus I in the electoral sejm. The followers of Frederick Augustus did not reconcile with the election, and on 5 October about 20 senators and 3,000 nobles assembled at the village of Kamienna near Grochów proclaimed Frederick Augustus as king Augustus III. He was supported by Russian and Saxon forces which invaded the territory of the Commonwealth. The political struggle developed into a civil war and resistance to the interventionists. That was a prelude to a war between France as a 
supporter of Leszczyński and Austria which backed Augustus III; this conflict was given the name of the War of Polish Succession.

In the eighteenth century in the case of a crisis it was commonplace for the nobles of the Commonwealth to organize themselves into confederations - temporary political unions of nobles. As the usual state institutions did not function effectively, confederations were efficient structures enabling the nobles to strive to implement their policies and at least partially to compensate for the weakness of state institutions. Thus on 5 October 1733, shortly after the election of Augustus III, his adherents formed a general confederation of the Polish Kingdom and the Grand Duchy of Lithuania (hereafter GDL); it was also known as the Confederation of Warsaw. The nobles of the palatinates and powiats (districts) opposed this puppet confederation created from above under the aegis of the interventionist Russian army. It was the first 'new-type' confederation, that is, it was formed in defiance of the dominating attitude of the gentry according to which the general confederation could only be considered representing the entire state if it was created on the basis of the confederations of the palatinates and powiats. ${ }^{1}$ In the Polish Kingdom Leszczyński's followers established their own general confederation democratically 'from below' on the basis of the confederations of the Polish palatinates and powiats in November 1734, the formation of which continued late in 1733 and early 1734 in response to Leszczyński’s universal charter, proclaimed in Gdańsk on 11 November $1733 .^{2}$

Meanwhile in the Grand Duchy of Lithuania Leszczyński's adherents formed their own confederation half a year earlier than their allies in Poland. The act of the GDL confederation was proclaimed in Vilnius on 5 April $1734 .^{3}$ This confederation is touched

${ }^{1}$ W. Stanek, Konfederacje generalne koronne w XVIII wieku (Toruń, 1991), p. 23.

2 Ibid., pp. 31-32.

${ }^{3}$ Konfederacja generalna województw y powiatów Prowincyi Wielkiego Xięstwa Litewskiego, na obrone ginacey wiary swiętey katholickiey, wolności, praw y swobód, dóbr szlacheckich, duchownych y swieckich, sub vinculo juramenti, przy dostojeństwie Majestatu Nayjaśnieyszego Króla JM Stanislawa, Pierwszego pana naszego milościwego, wolnemi glosami in solito loco libere między Wola y Warszawa in anno 1733 miesiaca septembra dwunastego dnia in campo electorali obranego. Uczyniona $w$ Wilnie Roku 1734, Miesiqca Aprili, 5 Dnia. The author of this article is aware of three copies of this publication, kept in Vilnius University Library, Department of Rare Books (henceforth VUB RSS), IV 30754; Warsaw, Archiwum Główne Akt Dawnych (AGAD), AR II, rkr. 2500, pp. 1-28; Cracow, Biblioteka Jagiellońska (henceforth JB), ms. 1047/IV, ff. 57-71. 
on in the reminiscences of Martynas Matuševičius (Marcin Matuszewicz). ${ }^{4}$ This issue and the Confederates' battles with the Russian army and the forces of Augustus III were dealt with more extensively by Tadeušas Oginskis (Tadeusz Ogiński). ${ }^{5}$

The Confederation of the GDL (and in particular its act) have not yet been researched by the historians. Stefan Truchim is the only one to present a survey of this subject in his work on the Polish Confederation of Dzików. However, he draws only on Oginskis' memoirs. ${ }^{6}$

The present paper is aimed at revealing the organization principles and the main stages of the General Confederation of the GDL.

The Formation of the General Confederation of the GDL The number of the adversaries of Frederick Augustus of Saxony in the GDL was significant, because his father Augustus II was widely disliked. On the eve of the interregnum these public sentiments were known in Russia as well. In his account of 21 August 1731 to the Russian tsarina Anna Ivanovna, the envoy to the Commonwealth Count Friedrich Löwenwolde presented the situation in the Commonwealth in great detail describing the feelings of the nobility, discussing the candidates for the Polish throne, characterizing the most influential noble families and the chances of their representatives to ascend the throne and the attitudes of these families to Russia. ${ }^{7}$ In Löwenwolde's opinion the hostility towards the Saxon (Wettin) dynasty was particularly strong in the GDL. Lithuanian nobles were confident that Augustus II had never been well-disposed towards the population of the Commonwealth and in particular to the nobles, in the terms of the account, to 'the Poles' and 'Catholics'. Therefore the envoy stated that there were numerous Leszczyński supporters in the GDL. The latter maintained that Leszczyński, having been elected once king and crowned as Stanislaus I, could aspire to ascend the throne of the Polish Kingdom again after Augustus II's death. The Russian envoy considered that the GDL nobles would resist the son's attempts to become king and would

${ }^{4}$ Pamiętniki Marcina Matuszewicza kasztelana Brzesko-Litewskiego 17141765, ed. Adolf Pawiński (Warsaw, 1876), t. 1, pp. 57-71.

5 'Pamiętnik Tadeusza Ogińskiego', ed. Kazimierz Bartoszewicz, Przegląd Historyczny, 1914, XVIII, z. 1, pp. 51-69.

${ }^{6}$ S. Truchim, Konfederacja Dzikowska (Poznań, 1921).

7 Arkhiv vneshnei politiki Rossiiskoi imperii (henceforth AVPRI), f. 79 (Snosheniia Rossii s Polshei, henceforth SRP), op. 79/1, 1731, d. 7a, ff. 80-103. 
back Leszczyński presuming that the duke Frederick Augustus would not meet the needs of the Commonwealth and becoming king would not adhere to the policy of peace in respect to neighbours. ${ }^{8}$

Seeking to form a general confederation of the GDL, Frederick Augustus' enemies met in Vilnius at the time when there was no Russian army in the city. It is not clear when the organizers gathered in Vilnius and when they started and how long the formation of such a confederation lasted, since no diary relevant to this has been found (if one ever existed).

The opponents of the General Confederation of the GDL issued an anonymous extensive 27-page brochure entitled Confederation alias a Plot Hatched in Vilnius in the First Days of April 1734 ...9 According to this title it could be deduced that the founders of the Confederation assembled in Vilnius on 1 April 1734 and that its formation lasted until 5 April - this is the actual date of the act. In the course of these days the Confederation was created, its leadership elected and the act proclaimed.

The Confederation was established in the traditional democratic way, i.e 'from below', on the basis of the confederations of the palatinates and powiats. There is hardly any information about these local confederations. It can only be presumed that their formation proceeded similarly to that in the Polish Kingdom at that time, the difference being only in that that in the autumn of 1733 the GDL was a Russian theatre of military actions. Nevertheless, the prior formation of confederations in the palatinates and powiats is mentioned in the very act of the General Confederation. ${ }^{10}$ The existence of the confederations of the palatinates of Vilnius and Trakai, of the Duchy of Žemaitija, of the powiats of Grodno and Lida is attested by the signatures of the marshals of these confederations in the Act of the General Confederation. Among the founders of the General Confederation there were 'the colonels' of the palatinates of Vilnius, Trakai and Minsk, of Žemaitija and of the powiats of Lida, Oshmiana and Grodno. The signatories of the Act included three delegates from Vilnius, nine from Oshmiana, five from Lida, three from

${ }^{8}$ Ibid., ff. 64, 68, ff.

${ }^{9}$ Confederacya alias spisek Wileński w roku 1734 Primis Aprilis uczyniony. Scaenice Per Glossam Refutatur. Vilnius, Library of the Lithuanian Academy of Sciences, Manuscript Department (henceforth LMAB RS), f. 148, b. 196.

${ }^{10} \mathrm{My}$... do ... Wilna ... zgromadzeni, y nie już tylko particularitater po Woiewództwach y Powiatach per prius, lecz już in universum skonfederowani manifestujemy sie, the Act of the Confederation, VUB RSS, IV 30754. 
Ukmergè, two from Braslav, two from Trakai, two from Žemaitija, three from Smolensk, one from Starodub, four from Polotsk, two from Novgorodok, four from Slonim, four from Volkovysk, two from Orsha, two from Pinsk, six from Minsk, one from Mozyr, and one from Livonia. None of the delegates called himself a signatory of Kaunas, Upyte, Brest, Mstislav or Rezekne. ${ }^{11}$

The anti-Saxon confederation elected the palatine of Vitebsk, Marcionas Oginskis, (Marcjan Ogiński) as its marshal. The GDL nobles considered him a clever man suitable for the post. As he was a senator, the act contained a provision for the egalitarian tradition of the Commonwealth's nobles that the senator's election to such a post would not be a precedent and would not limit the exceptional prerogatives of the nobles. ${ }^{12}$ Apart from the marshal, thirty-two counsellors were elected as representatives of the palatinates and powiats of the GDL. ${ }^{13}$ In addition to other powers, the marshal of the Confederation was granted some special privileges which belonged only to the king under normal conditions. It was the right to levy the nobles and to convene public meetings (ius convocandi). The marshal could convene public meetings (pro tractandis publicis negotiis zjazdów), appoint the judicial sessions of the confederation and special palatinate and powiat courts functioning during the interregnum, and having conferred with the counsellors summon the nobles of the palatinates and powiats. All that, however, could not infringe on the rights of the king (salvis Iuribus Majestatis).

Without their own armed forces, the confederates could only dream about the implementation of their plans. During the formation of the General Confederation of the GDL a part of the Lithuanian army, supporting Leszczyński, was engaged in battles against the Russian interventionist army. It was led by the strazinik (Lat. excubiarum praefectus) of Lithuania Antanas Aleksandras Pociejus (Antoni Aleksander Pociej), who on 17 September 1733 was appointed by Leszczyński as the general regimental officer (Lat. regimentarius)

${ }^{11}$ Ibid.

12 Ibid.: obraliśmy, ex Senatorio Ordine (co nie ma na czas przyszly trahi in sequelam, ani prejudicare zwykley Equestris Ordinis $w$ obieraniu Marszałka kompetencyi).

13 The palatinate of Vilnius, the powiats of Oshmiana, Lida, Ukmerge and Braslav, the palatinate of Trakai, the powiat of Grodno, the palatinates of Žemaitija, Novogrudek, Polotsk and Smolensk, the powiats of Slonim, Volkovysk, Pinsk and Orsha were represented by two counselors; the palatinate of Minsk and the powiats of Livonia, Starodub and Mozyr by one, ibid. 
of the armed forces of the GDL, i.e. the commander-in-chief in the interim. A. A. Pociejus participated in the creation of the Confederation and signed its Act. The counsellors of the Confederation were obligated to maintain contacts with the general regimental officer. The Confederation marshal and the general regimental officer were enjoined from doubling in their duties. ${ }^{14}$

Having solved the questions of the political and military management, the Confederation began regulating judicial issues. Monitoring the law-courts was an efficient means of controlling the nobles - it was a necessary prerequisite of a successful confederation. Two types of courts were projected. The functions of the central extraordinary court of the Confederation were entrusted jointly to the marshal and the counsellors. Its protection and competence must have been similar to those of the Supreme Tribunal. ${ }^{15}$ Interregnum courts (sqd kapturowy) courts had to continue functioning in the powiats. This provision was noteworthy. The further functioning of the interregnum courts created before the convocational sejm during the interregnum to replace the previous ordinary powiat courts of land and castle and the continuation of the suspense of the activity of the Supreme Tribunal of Lithuania had to emphasize the illegality of the crowning of Augustus III. The point was that Leszczyński had only been elected and had not yet been crowned, consequently, in the opinion of his adherents, the interregnum courts had to continue functioning. True, the interregnum court judges, who recognized Augustus III, were dismissed. ${ }^{16}$

Meanwhile Augustus III's followers, supported by the Russian forces, endeavoured to resume the activity of all previous courts, including the Supreme Tribunal, on behalf of Augustus III from the very moment of his coronation. The General Confederation of the GDL categorically opposed these measures and by its Act annulled all the decrees and court decisions, issued on behalf of Augustus III. ${ }^{17}$

The Act of the Confederation contained the reasons and aims of its creation and presented information on the situation in the GDL. Russia was accused of breaking the peace treaties and sending

${ }^{14}$ Ibid.

${ }^{15}$ A jako Tribunal Wielkiego Xięstwa Litewskiego, tak wielu prawami de securitate sua sq obwarowane, tak in fundamento tychize Praw Sady Konfederackie ut eadem immunitate gaudeant, et in Convulsores publicae tranquilitatis peny lege publica opisane extendowane byly decernimus, ibid.

${ }^{16}$ Ibid.

${ }^{17}$ Ibid. 
its troops to the Commonwealth. The document stressed that it was due to the military intervention of Russia and Saxony and the efforts of some traitors of the Commonwealth that the Saxon seized the throne of the Polish Kingdom. Therefore the confederates denounced Augustus III as a usurper. ${ }^{18}$

The Act also reported the crimes of the Russian forces: soldiers burned towns, estates and villages, robbed the peasants of foodstuffs and forage, plundered churches and monasteries, arrested clergymen and raped women. It mentioned the pillage of Vilnius Cathedral (St Casimir's Chapel) and other churches and monasteries in the city. In many places the Russian army set up its garrisons, established depots of foodstuffs and forage and made the population provide them with supplies. ${ }^{19}$

Some minor matters were also mentioned in the Act. The recordkeeper of the castle court of the Orsha powiat Pranciškus Podbereskis (Franciszek Podbereski), having taken the court documents and joined Augustus III's adherents and the Russian army, was compelled to appear before the court of the Confederation. The artillery general of the GDL Leonas Sapiega (Leon Sapieha) was urged to carry out his duties in the army and to swear an oath of allegiance to the marshal of the Confederation. Fines were fixed for the deserters. Embezzlement of the property of widows and the dead was forbidden. Antanas Rudamina Dusetiškis (Antoni Rudomina Dusiatski), podkomorzy (Under-Chamberlain) of Braslav, having acted as an envoy of the Commonwealth to Petersburg and subsequently not reported to the sejm on the results of his mission, was requested to appear before Leszczyński to present an account of his assignment. The Confederation of the GDL appointed the vice-palatine of Trakai, Kazimieras Ukolskis (Kazimierz Ukolski), and the cup-bearer of Oshmiana, Mykolas Širvinskis (Michał Szirwiński), as envoys to Leszczyński. ${ }^{20}$

The Act stated that the Confederation would last until peace and calm were established in the Commonwealth. It would be dissolved when the battles died down. ${ }^{21}$

All members of the Confederation had to swear an oath. All ministers, senators, state dignitaries and judiciary, not yet sworn in,

\footnotetext{
18 Ibid.

${ }^{19}$ Ibid.

${ }^{20}$ Ibid.

${ }^{21}$ Ibid.
} 
had to take an oath before the marshal and counsellors in six weeks' time. An exception was made only for those who resided at Leszczyński and carried out his assignments. All the powiat officials, nobles, representatives of Magdeburgian town municipalities had to swear allegiance in the presence of the marshals, colonels or standard-bearers of the confederations of palatinates or powiats at the post-sejm dietines. The latter officers personally had to inform the marshal and counsellors of the Confederation about these oaths. The military took an oath to the general regimental officer. However, no oath could remove the guilt of 'traitors', i.e those who had signed the election of Augustus III and the Confederation of Warsaw. ${ }^{22}$

The palatine of Vitebsk, M. Oginskis, the general marshal of the Confederation, was the first to sign the Act. He was followed by Bishop Mykolas Zienkovičius (Michał Zienkowicz) of Vilnius and Bishop Boguslovas Korvinas Gosievskis (Bogusław Korwin Gosiewski) of Smolensk. The signatories included three senators: the castellan of Smolensk Jan de Campo Scipion, the castellan of Polotsk Mykolas Šemeta (Michał Szemet) and the castellan of Novgorodok Antanas Oskierka (Antoni Oskierka); eight state dignitaries: the Bishop Suffragan of Vilnius and GDL referendary Jurgis Kazimieras Ancuta (Jerzy Kazimierz Ancuta), the straznik of the GDL A. A. Pociejus, the treasurer of the GDL Jonas Odachovskis (Jan Odachowski), Referendary Dominykas Valavičius (Dominik Wołłowicz), the notary of the GDL Mykolas Juozapas Masalskis (Michał Józef Masalski), the deputy cup-bearer of the GDL Aleksandras Pociejus, the cupbearer of the GDL Juozapas Ščytas (Józef Szczytt), and the procurator of the GDL Stanislovas Antanas Bužinskis (Stanisław Antoni Burzyński). Many other creators of the Confederation were powiat officials. $^{23}$

\section{The Struggles of the Confederates against the Russian Forces} and Augustus III's Adherents At that time the supreme commander of the Russian interventionist army in Lithuania LieutenantGeneral Lev Izmailov was in Kavarskas. Having been informed about the formation of the General Confederation of the GDL, he issued a manifesto in which he stated that Russia, seeking to pre-

22 ... takowi ullo modo wykonana przysięga zaszczycać, tym barziey ochraniać się będa, lecz rigori ac executioni pen ... irremissibiliter sine ulla clementia subjacebunt, ibid.

${ }^{23}$ Ibid. 
serve peace in Europe and quiet in the neighbouring state and also to prevent the infringement of the constitution and the law, had to send its forces into the Commonwealth. The Russian general promised not to feel sorrow for those who failed to recognize Augustus III as their ruler, and, in his words, spilled blood and destroyed the well-being of the people; he threatened to lay their houses flat and warned that neither people nor property would be spared. ${ }^{24}$

On 30 April Izmailov's corps left Kavarskas and marched towards Vilnius. ${ }^{25}$ As the enemy advanced, the confederates and their troops withdrew from the capital. Following the Russian occupation of Vilnius, the palatine of Novgorodok Mykolas Faustinas Radvila (Michał Faustin Radziwiłł), the notary of the castle court of the Orsha powiat P. Podbereskii and the lieutenant-colonel of the Russian army Georg Liewen set about re-establishing the activity of the Supreme Tribunal of the GDL. With this aim in view, they secured Augustus III's universal charter. ${ }^{26} \mathrm{M}$. F. Radvila sent the universal out to the nobles with the request to convene the dietines and elect delegates to the Supreme Tribunal of the GDL. ${ }^{27}$ The Tribunal session opened in Vilnius on 10 May under the protection of Russian forces. $^{28}$ The renewal of the activity of the Supreme Tribunal of the GDL meant a notable victory for the supporters of Augustus III and the Confederation of Warsaw.

Avoiding an encounter with the Russian forces led by Izmailov and Major General Rudolf August von Bismarck, the army subject to the confederates and the regimental officer A. A. Pociejus withdrew from Vilnius to Oshmiana at the beginning of May; ${ }^{29}$ afterwards they retreated still farther to the palatinate of Novgorodok. There they were going to stay on the estates of M. F. Radvila, a supporter of Augustus III. ${ }^{30}$ The confederate camp was set up in

${ }^{24}$ A copy of Izmailov's manifesto to the population of the GDL, Kavarskas, Apr. 1734, Rossiiskii gosudarstvennyi arkhiv drevnikh aktov (henceforth RGADA], f. 177 , op. 1, 1734, d. 16, 1. 105.

${ }^{25}$ Izmailov to tsarina Anna Ivanovna, report of 30 (old style 19) Apr. 1734, Kavarskas, ibid., f. 104.

${ }^{26}$ Izmailov to the tsarina, report of 30 (old style 19) Apr. 1734, Ukmerge, ibid., ff. $45-48$.

27 Ibid.

${ }^{28}$ Izmailov to the tsarina, report of 6 June (old style 26 May) 1734, Vilnius, ibid., d. 16, ff. 120-121.

29 Pamiętniki Marcina Matuszewicza, pp. 34-35.

${ }^{30}$ Izmailov to the tsarina, report of 6 June (old style 26 May) 1734, Vilnius, ibid., f. 177, op. 1, d. 16, ff. 120-121. 
Korelichi and its environs. ${ }^{31}$ Nobles from the GDL powiats gathered there, and their forces grew nearly up to 8,000 men. ${ }^{32}$

Here the activity of the Confederation (Confederate courts, etc.) was continued. However, in the camp and in the army there was no order and discipline. Hunting and revelry were frequent. A.A. Pociejus himself drank much and did not pay attention to military discipline. The commanders of the units resided in the homes of peasants or in inns; the officers, as a rule, did not control their detachments and sentry posts and entrusted those duties to their lieutenants. The soldiers were not paid regularly, ${ }^{33}$ since the majority of the Lithuanian nobles did not intend to burden themselves with taxes. The scarcity of resources was compensated by plundering the estates of opponents, devastating villages and imposing all kinds of levies on them.

One of Augustus III's military supporters, the palatine of Novgorodok M. F. Radvila made attempts to win over the leader of the Lithuanian Confederation A. A. Pociejus. Early in May he sent one of his officers to Pociejus with this task. The messenger remained in the camp of the Confederates. ${ }^{34}$ Izmailov also promised Pociejus the benevolence of the Russian empress in case he agreed to defect to the enemy. ${ }^{35}$

The regimental officer A. A. Pociejus' hopes for victory were fading gradually. In August 1734 he sent a nobleman of his to the regimental officer Mykolas Servacijus Višnioveckis (Michał Serwaci Wiśniowiecki) of a part of the Lithuanian army siding with M. F. Radvila, the GDL chancellor and Augustus III in order to learn the conditions on which he could gain favour with the King. ${ }^{36}$ Following the siege and capture of Gdańsk by the Russian army and Leszczyński's flight to Prussia, A.A. Pociejus transferred the control of the confederate army to his brother A. Pociejus, vice cup-bearer of the GDL, in Slonim. He himself and the marshal of the Confederation M. Oginskis endeavoured with 3,000 horsemen to reach Prussia and meet Leszczyński there. ${ }^{37}$ However, they managed only

31 Pamiętnik Tadeusza Ogińskiego, p. 70.

32 Pamiętniki Marcina Matuszewicza, p. 36.

${ }^{33}$ Pamiętnik Tadeusza Ogińskiego, pp. 70-71.

${ }^{34}$ Izmailov to the tsarina, report of 6 May (old style Apr. 26) 1734, Skaruliai, RGADA, f. 177, op. 1, 1734, d. 16, ff. 113-116.

${ }^{35}$ Ibid.

${ }^{36}$ Izmailov to the tsarina, report of 16 Aug. (old style 5 Aug) 1734, Repel, ibid., ff. 189-190.

37 Pamiętniki Marcina Matuszewicza, p. 41. 
to reach Brest. ${ }^{38}$ Meanwhile the remaining Confederates suffered a crushing defeat not far from the town of Sielec at the Jasiołda River on 19 August $1734 .{ }^{39}$

The pen was also a weapon in the struggle. Noteworthy in this respect was the aforementioned Confederacya alias spisek Wileński, directed against the Confederates of the GDL. ${ }^{40}$ The authors of this brochure claimed that Leszczyński's election was unlawful, since the sejm of 1717 pronounced him banished, sequestrated his property and deprived him of the right to ascend the throne of the Polish king at any time in the future. The Primate Teodor Potocki was also attacked for ignoring the admonition of Russian ministers not to elect Leszczyński; contrarily, financially supported by France both in the Convocational and Election Sejms he contributed to the election. The authors of the brochure argued the legality of Augustus III's election and coronation, accused the Confederates of the GDL of devastating the country, plundering gentry property, and killing their opponents. He asked rhetorically whether it was right that thousands had perished in the Commonwealth because of one man. The booklet also contained other accusations against the Confederates and justification for the deployment of the Russian forces into the Commonwealth. ${ }^{41}$ The contents of the booklet show that it was published after the Gdańsk capitulation and Leszczyński's flight to Prussia (he left Gdańsk on 27 June, crossed the Austrian border on 3 July and arrived at Königsberg on 8 August).

The leadership of the General Confederation of the GDL had been informed in advance about the intention to form a general confederation of the Polish Kingdom. In August Leszczyński issued an appropriate universal charter and sent his delegates to Poland to represent him at the venue of the Polish Confederates. Both delegates - Juozapas Sapiega (Józef Sapieha) and the starosta of Skirsnemunė Antanas Eperijašas (Antoni Eperyaszy) were closely associated with the Confederates of the GDL. Two delegates of the Lithuanian Confederation - the land court judge of Upyte powiat, captain (rotmistrz) and councellor of the General Confederation of the GDL Motiejus Pranciškus Marcinkevičius (Maciej Franciszek

${ }^{38}$ Ibid., p. 44.

${ }^{39}$ Izmailov to the tsarina, report of 19 August (old style 8 Aug) 1734, Sielec, RGADA, f. 177, op. 1, 1734, d. 16, f. 192.

40 See note 9.

${ }^{41}$ Confederacya alias spisek Wileński, LMAB RS, f. 148, b. 196. 
Marcinkiewicz) and the GDL treasurer, the starosta of Batakiai and councellor of the Confederation J. Odachovskis - were sent to the congress of the Polish Confederates at the end of October 1734. Early in November, after having arrived at Dzików, the palatinate of Sandomierz, they signed the act of the Confederation of Dzików. They also brought the leadership of the Polish General Confederation a letter, informing the Polish Confederates about the formation of the Lithuanian General Confederation, wishing the Poles success and offering them to send a joint delegation of representatives from both Confederations to Leszczyński in Prussia. ${ }^{42}$ The Confederation of the GDL also expressed its readiness to foster military and political unity with the Polish Confederates and to uphold the union between the GDL and Poland. ${ }^{43}$

The council of the General Confederation of Dzików, residing in Kołbuszowa between 15 and 25 November, sent a return delegation - Michał Szydłowski and Stefan Trembiński - with a personal letter to the marshal of the Lithuanian Confederation M. Oginskis. The Polish Confederates expressed their gratitude for the information about the activity of the General Confederation of the GDL and submitted a proposal to create an integrated confederation, if the necessity arose. They also invited Oginskis and A. A. Pociejus to come to Jarosław, where the general council of the Confederation of Dzików was going to move. ${ }^{44}$

M. Oginskis and A. A. Pociejus did not go to Jarosław; the Lithuanian Confederation only sent a letter, dated 5 January 1735, in which it congratulated Adam Tarło, elder of Jasielsk, on being elected marshal of the Confederation of Dzików, promised to be loyal to Stanislaus I, maintain contacts and keep on informing about the events. The letter, however, did not contain any mention about a joint general council. Thus, the contacts between the two confederations remained rather weak. The declarations of solidarity stopped short of closer formally valid union contacts. ${ }^{45}$ The leaders of the General Confederation of the GDL were supposedly not inclined to become dependant on the Confederation of Dzików and pursue its

42 Truchim, Konfederacja Dzikowska, pp. 72, 76.

43 ... in unione animorum et armorum et in dissolubile nexu (my emphasis to show Truchim's mistake; the phrase should be read as et indissolubile nexu, ibid. p. 68 .

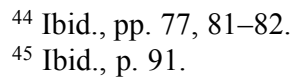


policy. Possibly that was the reason why the Lithuanian representatives did not go to Jarosław.

Some friction between the General Confederation of the GDL and the supporters of Leszczyński in Poland appeared at once, when news about the foundation of the Lithuanian Confederation reached Poland. According to the report of Antoni Eperyaszy, a Lithuanian confederate who was active at that time in Poland, the Poles and probably the king, Stanisław Leszczyński, were not satisfied because, in their view, the king and the Primate of the Catholic Church in the Polish-Lithuanian Commonwealth, the archibishop of Gniezno, were being treated too coolly, the leaders of the Lithuanian Confederation were concentrating in their own hands too much power there by limiting royal power, and because there were no declarations of intent to join a common confederation with the Polish Crown. ${ }^{46}$

The supporters of King Stanisław in Poland gathered in Dzików and made an attempt to solve the problem of relations between the Lithuanian and Polish Confederations unilaterally. The Confederation proclaimed in Dzików formally, as it bears witness, was not that of the Polish Crown alone, but of 'the Polish Crown and the Grand Duchy of Lithuania'. ${ }^{47}$ Chapter 54 of the Act of this Confederation says that the confederates acknowledged the legitimacy of the General Confederation of GDL and would allow it to continue its activity. ${ }^{48}$ Thus, the Polish Confederation regarded the Lithuanian Confederation as subordinate to the Dzików Confederation. Such an interpretation was based on the fact that the Dzików Confederation Act was signed also by the two envoys of the Lithuanian Confederation (they signed the Act under the condition that the General Confederation

${ }^{46}$ Antoni Eperyaszy (Eperieszy) to Józef Sapieha, the court treasurer of the GDL, Jarosław 11 V 1734, Archiwum Główne Akt Dawnych, Archiwum Ordynacji Roskiej, LII / 37, ff. 47-49.

${ }^{47}$ Konfederacya Generalna Stanów Koronnych y Wielkiego Xięstwa Litewskiego na Walnym Ziezdzie w Dzikowie pod Sandomierzem Postanowiona Dnia V. Miesiąca Listopada Roku Panskiego MMCC. XXXIV, Biblioteka Czartoryskich, ms. 578, ff. $109-161$.

48 [§. 54 Konfederacya W.X.L.] Konfederacya Prowincyi W.X.L. Diplomate Regio approbowana, poniewaz przez Delegowanych Wielmoznych Ichmciow Panow Iana Odachowskiego Skarbnego W.X.L., Matheusza Marcinkiewicza Sędziego Ziemskiego Upitskiego, Poslów, do Generalney Naszey Koronney accessit Konfederacyi, pomienioną Prowincyi W.X.L. Konfederacyą circa sancita oney, zachowuiemy, Manutenere przyrzekamy, \& junctis Consiliis ac auxiliis, publicae prodesse saluti deklaruiemy, ibid., f. 142. 
of the GDL would not be restricted in any of its prerogatives ${ }^{49}$ ). Nevertheless, 'the General Confederation of the GDL', founded in Vilnius, and 'the General Confederation of the Polish Crown and Grand Duchy of Lithuania', founded in Dzików, continued to act as independent political and military allies, both subordinated directly to King Stanisław Leszczyński and without any signed act of unification.

The General Confederation of the GDL sent its messengers the notary of the GDL M. J. Masalskis and the Confederation marshal's son, the commander of a detachment Tadeušas Oginskis to Leszczyński, staying in Königsberg. They had to ask the king to provide financial support for the upkeep of the army and to get muskets. The delegates were received cordially by Leszczyński, who, however, did not have the necessary bills of exchange, and the mission ended in failure. Besides, the task was fraught with danger the creditors were going to arrest Oginskis for his father's debts. Therefore the messengers of the Lithuanian Confederation had to leave Königsberg in a hurry. ${ }^{50}$ The failure to get financial support complicated the situation of the General Confederation of the GDL. The confederate troops needed weapons and money for salaries. Obligations were imposed on the estates of the opponents to ease permanent food and forage shortages.

Confederate powiats rallied the levée-en-masse of the nobles. However, the summoned nobles did not play any significant role in defending Leszczyński's throne. Many of them brought their serfs to the Confederate army. Recruited by force and poorly armed, peasants deserted during engagements with Russian troops.

The army of the General Confederation of the GDL was weak. It could hardly withstand the attacks of the Russian interventionist army and the regular troops of the GDL, loyal to Augustus III. The changes in the leadership of the Lithuanian Confederate army did not contribute to the improvement of the situation either. Following the illness of the regimental officer A. A. Pociejus late in 1734, the

${ }^{49}$ Od W. Xięstwa Litewskiego Delegati. Accedendo Nomine Prowincyi W.X.Lit: do Konfederacyi Koron: podpisuię. Jan Odachowski, Skarbny W.X.Lit: Stolnik Zmuydzki, Starosta Botocki, posel z W.X.Lit: Salva Manutentione in toto Konfederacyi W.X.Lit: Generalney. Accedendo Nomine Prowincyi W.X.Lit: do Generalney Koronney Konfederacyi, cum Manutentione in toto Generalney W.X.Lit: Konfederacyi podpisuię się. Mateusz Marcinkiewicz, Sędzia Ziemski Upitski, Konsyliarz y Posel Skonfederowanego W.X.Lit:, ibid., f. 159.

${ }^{50}$ Pamiętnik Tadeusza Ogińskiego, p. 73. 
control of the army was taken over temporarily by the notary of the GDL M. J. Masalskis. Under his command the army left the GDL and was deployed on the border with East Prussia, in the environs of Augustów and Szczuczin at the end of December 1734. ${ }^{51}$ The Confederates were based partly at Grodno. Late in March 1735 several thousand troops of Polish Confederates came to the border with Prussia, too; they were led by the palatine of Volhynia Michat Potocki. Afterwards some Polish troops, not getting the promised support from Königsberg, crossed a narrow strip of East Prussia, entered Warmia and stopped at Biskupec in the hope of receiving the money and finishing wintering. ${ }^{52}$ There the Confederates stayed for some weeks. During their stay at Reszel the marshal of the Confederation M. Oginskis left for Königsberg. He was joined by the marshal of the Confederation of Dzików A. Tarło; this decision of theirs had been known in Königsberg since late February. ${ }^{53}$ After the marshals' emigration there appeared a sort of government-in-exile, comprising the king and the highest echelons of power of the GDL and the Polish Kingdom. Here, leaving their troops, retreated many other Lithuanian and Polish Confederates, among them the butler of the GDL Petras Sapiega (Piotr Sapieha). ${ }^{54}$ Warmia, however, proved not to be a very safe place for the Confederates. Russian troops led by the Generals Biron and Izmailov invaded the region, defeated the Confederates in several skirmishes and even crossed the East Prussian border in pursuit of them. For fear of further Russian assault, preparations were made for the withdrawal of Leszczyński and the leaders of the Confederation from Königsberg. The Russians, however, retreated. ${ }^{55}$ During the Russian advance, the regimental officer A. A. Pociejus had left his army in Warmia. Retreating to Prussia, he again handed over command to M. J. Masalskis. Before leaving he offered the commanders of the troops some options: to return to the GDL and continue the struggle, to retreat to Prussia or to

${ }^{51}$ Pamiętniki Marcina Matuszewicza, pp. 52-53.

${ }^{52}$ S. A. Achremczyk, 'Warmia wobec wydarzeń z lat 1733-1736', Komunikaty Mazursko-Warmińskie, 1985, nr. 1-2, pp. 46-47.

${ }^{53}$ F. M. Ossoliński do J.A. Załuskiego, Królewiec, 2402 1735, Korespondencja Józefa Andreja Zatuskiego, 1742-1736, ed. B. S. Kupść and K. Muszyńska (Wrocław, 1967), p. 261.

${ }^{54}$ Ossoliński to Załuski, Königsberg, 2903 1735, Korespondencja Józefa Andreja Zatuskiego, p. 299.

${ }^{55}$ S. A. Achremczyk, 'Emigranci polscy w Królewcu w XVIII wieku', Studia Warmińskie, 32 (1995), p. 195. 
disperse. Basing himself on illness, the commander of the Polish Confederates M. Potocki also retreated to Prussia.

The remnants of the Lithuanian Confederate army again returned to northern Mazovia through East Prussia. The changes in the leadership continued: before retreating to Königsberg at the town of Koln, M. Masalskis transferred the command of the forces to the straznik polny (praefectus excubiarum campestris) of the GDL Martynas Antanas Paškovskis Lanckoronskis (Marcin Antoni Paszkowski Lanckoroński). At that time the Confederate army actually did not exist any more - the majority of the soldiers had dispersed. Paškovskis and a detachment of his soldiers reached the forests of Łomża, joined the local partisans, the so-called kurpiowie, and continued the struggle. The colonel Eperiašas and his unit arrived in Moldova and attempted to put up resistance in the border region, in the environs of the Chocim fortress, controlled by the Turks. Only the detachment of T. Oginskis, the son of the Confederation marshal, continued the fight back against the Russian army and the adherents of Augustus III. However, incessantly attacked on all sides and badly affected by desertions, the detachment gradually decreased. In May 1735 T. Oginskis dissolved his unit in Liubinich at Bobruisk, thus ending a losing battle. In the middle of July he himself secretly crossed the Prussian border and arrived at Tilsit and subsequently Königsberg. ${ }^{56}$.

The Confederation of Dzików declined in the Polish Kingdom as well. Financial shortages were acute, and soldiers were not paid. Scores of them deserted to the camp of Augustus III. In the spring of 1735 many Dzików Confederates and some of their troops withdrew to Prussia.

The Activity of the Lithuanian Confederates in Emigration In the beginning the Confederates of the GDL and Dzików gathered in their separate sessions, chaired by their own marshals. The two sides failed to reach agreement. When the marshal of the Confederation of Dzików Tarło invited the leaders of both sides for negotiations at his place, the Lithuanians did not turn up. They requested that the Poles should come to them. Finally both parties agreed to meet on neutral ground. Since 5 December 1735 joint sessions of the Lithuanian and Polish Confederates had taken place in a Jesuit church. ${ }^{57}$

${ }^{56}$ Pamiętnik Tadeusza Ogińskiego, pp. 81-83.

${ }^{57}$ A. M. Wodziński, 'Król Stanisław Leszczyński w gościnie Pruskiej', Rocznik Gdański, 1937, XI, p. 203; Truchim, Konfederacja Dzikowska, p. 125. 
It is maintained that around 2,000 nobles found refuge in East Prussia. ${ }^{58}$ Individual nobles and noblemen, coming to Prussia, joined the émigré Confederates. More influential emigrants included the Bishop of Vilnius, Bishop Aleksandras Horainas (Aleksander Horain) of Žemaitija, the majority of the members of both chapters, the elder of Merkinè Antanas Kazimieras Sapiega (Antoni Kazimierz Sapieha), and others. ${ }^{59}$ The military predominated among the refugees, and many of them wanted to remain in Königsberg, closer to Leszczyński. However the Prussian authorities, sought to disperse them throughout the entire province. A part of the Confederates came back to the GDL. Some intended to go to Žemaitija via Tilsit and continue the struggle. ${ }^{60}$ But that enterprise was not realized.

In emigration the Confederates closely watched the events in the Commonwealth. That was attested in their activities and in the resolutions of their sessions. When Augustus III decided to call the Pacification Sejm on 27 September 1735, the Confederations of the GDL and Dzików immediately issued their joint manifesto 'To the Commonwealth and the Whole of Europe', protesting against that sejm and declaring that they would not accept Augustus III and would remain loyal to the lawfully elected ruler Stanislaus I. ${ }^{61}$ The Pacification Sejm, held between 27 August and 8 November 1735, ended in failure. It was attended by a large number of Leszczyński's adherents, requiring the withdrawal of Russian and Saxon forces from the Commonwealth and protesting against the election of the sejm marshal. Thus the sejm did not even start its work.

In the aftermath of defeat in the armed struggle, France was the only hope of the Confederates and Leszczyński. They intently watched the course of hostilities between Austria and France taking place along the Rhine and in Italy. The concentration of the Confederates in Prussia was exploited by France in its strategy. They could go into battle against Augustus III at any time and hold the Russian forces down in the Commonwealth, thus preventing Russia from supporting Austria against France. The money received by Leszczyński from Versailles enabled him to sustain the former Confederate army of the GDL in Warmia with 200,000 livres in April 1735. ${ }^{62}$ Between the

\footnotetext{
58 Achremczyk, 'Emigranci polscy’, p. 193.

${ }^{59}$ Ibid.

60 Truchim, Konfederacja Dzikowska, p. 112.

${ }^{61}$ Ibid., p. 115.

${ }^{62}$ E. Cieślak, Stanisław Leszczyński (Wrocław, 1994), p. 182.
} 
end of 1734 and September 1735 France forwarded 1,200,000 livres to Königsberg to finance the activities of the Confederates and Leszczyński. ${ }^{63}$

The French forbade Leszczyński to inform the Confederates about the size of the sums sent. That money was supposed to be at the disposal of Leszczyński and L'Anglais, a Cambrais canon, who came to Königsberg at the beginning of December 1734 and was authorized to represent the policy of France. ${ }^{64}$ Leszczyński maintained contacts with Versailles through the canon L'Anglais and the French ambassador in Berlin Marquis Joachim Chétardie. However, at the beginning of 1736 France stopped sending money for the Confederates in Königsberg.

The conditions of the Confederates in Prussia were poor, since many of them were simply penniless. The income of Leszczyński's court in Königsberg was insufficient. The Confederates had to apply for loans to local merchants and inhabitants. Leszczyński asked the burghers of Königsberg to extend credits to the refugees and assured them that the loans would be paid off.

The Confederates and Leszczyński himself were inadequately acquainted with European politics and, in particular, they overestimated the support of France. They pinned their hopes on the treaty between France and Leszczyński (and the General Confederations supporting him), signed on 28 September 1735 . However, when the noncommittal contents of the treaty became evident, the councils of the Confederations did not want to ratify it. They agreed to do that only when Leszczyński reassured them about financial subsidies and an auxiliary corps of 30,000 French troops. ${ }^{65}$ Consequently they were shocked deeply by the truce signed by Austria and France in Vienna on 3 October 1735. At first they simply refused to believe it ('mówia, że to bajki'). ${ }^{66}$ On 6 December 1735 a copy of the articles of a preliminary peace accord was brought to Königsberg by Piotr Orlik. The illusions were shattered. One of the articles envisaged Stanislaus I's renunciation of the throne. ${ }^{67}$

${ }^{63}$ Ibid., p. 163.

${ }^{64}$ Ibid., pp. 153-154.

${ }^{65}$ Achremczyk, 'Emigranci polscy’, p. 196.

${ }^{66}$ W. H. Sierakowski to J. A. Załuski, Königsberg, 1810 1735, Korespondencja Józefa Andrzeja Załuskiego, p. 478.

${ }^{67}$ Truchim, Konfederacja Dzikowska, p. 122. 
Although France managed to win some gains in the war against Austria and the diplomacy of Versailles managed to neutralize Great Britain and Holland, it nevertheless failed to form an effective coalition of the states, capable of successfully continuing the war against Russia and Austria. Therefore both sides had to make compromises during the negotiations in Vienna. France acknowledged the Pragmatic Sanction and stopped supporting Stanislaus I and the Confederates. Austria consented to the request that the Duchy of Lorraine and Bar, occupied by the French army, would be handed over to Leszczyński and on his death would revert to France. According to the terms of the treaty of Vienna, Leszczyński had to renounce his claims to the Polish throne. Though he administered Lorraine and Bar as a duke, he was allowed to title himself king. In the Commonwealth Augustus III was recognized as its ruler. The affairs of the Confederates were dealt with only in a few words in the treaty; they were granted a general amnesty. ${ }^{68}$

On 19 December 1735 a joint session of the Confederations decided, on the suggestion of the notary of the GDL Masalskis, to dissuade Leszczyński from renouncing the throne. The Confederates feared that Leszczyński, having secured the loans, would leave the refugees to their own devices. The nobles were also tied to the Prussian king by their commitment to deliver two and more 'giants' for his army in return for political asylum. The lenders began to require that the loans be paid off. The finances sent from France were insufficient, and the Confederates had no other ways of getting the necessary sums. They even tried to find out where the treasurer of Poland Francyszek Maksymilian Ossoliński had hidden the Crown Treasury, but they did not succeed. ${ }^{69}$

The defeat of the Confederates was obvious. Therefore the Confederates debated with Augustus III's adherents about the way Stanislaus I should resign rather than about the resignation as such. The form proposed by the Confederates was unacceptable to Russia which feared fresh unrest in the Commonwealth. In the talks on Stanislaus I's renunciation, the Confederates were inclined to accept Prussia's mediation on the advice of the notary of the GDL Masalskis and the palatine of Lublin Jan Tarło. ${ }^{70}$

${ }^{68}$ Cieślak, Stanisław Leszczyński, p. 171.

${ }^{69}$ Truchim, Konfederacja Dzikowska, pp. 126-127.

${ }^{70}$ Ibid., p. 127. 
The Confederates placed their hopes, which were fostered by Berlin's emphatically outright hostility to Saxony and friendliness towards Leszczyński, on Prussia. The Prussian King Friedrich Wilhelm, well known for his stinginess, gave him bodyguards, a 300 -thaler monthly pension and settled him in the castle of Königsberg. The heir to the throne was also well disposed towards the expatriate king and the Confederates. ${ }^{71}$ An increased reliance on the Prussian King was encouraged by his endeavours to convince Leszczyński not to give in and with the support of his adherents to oppose the activity of the pacification sejm, convened by Augustus III in 1735. However, this friendliness proved simulation, and Berlin's motives were selfish.

As early as 1732 the Prussian King offered Augustus II to cede the Polish Pomorze to Prussia in exchange for the support of Augustus' son to ascend the throne of the Commonwealth. In actual fact, that was a scheme for partitioning Poland-Lithuania. In the turmoil of the interregnum Berlin expected to get territorial concessions from Saxony and Poland (in the latter case with respect to Elbing) in exchange for the recognition of Augustus III. Although the Austrian Emperor coaxed Augustus III into accepting these conditions, at the beginning of 1734 Augustus refused to admit them. ${ }^{72}$

In that situation Friedrich Wilhelm perceived that it would be easier to win territorial concessions from the opposite camp and consequently he offered political asylum to Stanislaus I and his followers. The Königsberg negotiations with Leszczyński concerning the transfer of the Commonwealth's lands (i.e. those separating Brandenburg from East Prussia) were conducted in secret without any information of the other Confederates. Besides, the king of Prussia wanted to get the Duchy of Courland for his younger son. Afterwards he limited his request to the area between Brandenburg and Prussia including the cities of Elbing and Braniewo (Braunsberg). France was to act as guarantor in the cession of this territory. Leszczyński avoided such formal commitments saying that the king of the Commonwealth was not authorized to take such decisions. ${ }^{73}$

${ }^{71}$ Achremczyk, 'Emigranci polscy’, p. 192.

72 J. Staszewski, 'Emigracja polska w Prusach Książęcych. Przyczynek do historii stronnictwa pruskiego w Polsce w XVIII wieku'; idem, 'Jak Polskę przemienic w kraj kwitnący ...', Szkice $i$ studia z czasów saskich (Olsztyn, 1997), pp. 158-159.

${ }^{73}$ Ibid.; Wodziński, 'Król Stanisław Leszczyński', pp. 177-203; Achremczyk, ‘Emigranci polscy', p. 192. 
Friedrich Wilhelm I expected to profit from the Franco-Austrian war - he laid claim to the Duchies of Jülich and Berg in Rhineland, and he also intended to deprive the Habsburgs of Silesia. Finally he hoped that the Commonwealth would confer the title of king of Prussia on him. The Commonwealth did that only in 1764 .

Having learnt about the preliminary truce, which turned out to be contrary to his expectations, Friedrich Wilhelm I changed his attitude towards the refugees in East Prussia. In the first place, he forbade them financial assistance, and accordingly the municipality of Königsberg issued a royal decree. ${ }^{74}$ So that indebted Confederates could not abscond, the commander of East Prussian forces Lieutenant General Johann von Katt, implemented the requirement of the royal decree of 17 December 1735 and allowed Confederates to leave Prussia only with special passports signed by him. ${ }^{75}$ The civilian and military authorities were instructed to carry out this order scrupulously and prevent the Confederates from leaving the province in secret. ${ }^{76}$ Early in January Katt requested the nobles residing in Königsberg to keep their promise and to present two tall conscripts for the Prussian army. The Confederates were forbidden even to go outside the city gates. They were like detainees, and some of them began looking for support among more influential people in the opposite circles and among their relatives in the Commonwealth. ${ }^{77}$

On 28 November 1735 the King Louis XV of France and his foreign minister, Chauvelin Germain, sent letters to Leszczyński and Canon L'Anglais informing about their agreements in Vienna in great detail. The letters reached the addressees about 10 of December. ${ }^{78}$ In his letter Louis XV enclosed a project of the act of Leszczyński's renunciation of his claim to the throne; the King also permitted him to make some amendments. L'Anglais was to dispatch the signed document to Paris without delay. The renunciation procedures had to be kept in secret from the Confederates. ${ }^{79}$ Leszczyński complied with the French king's will. On 27 January 1736 he secretly signed the renunciation act and a universal charter, in which he informed his subjects that they could regard themselves free from the oath of

\footnotetext{
${ }^{74}$ Cieślak, Stanisław Leszczyński, p. 170.

${ }^{75}$ Staszewski, 'Emigracja polska', p. 160.

${ }^{76}$ Cieślak, Stanisław Leszczyński, p. 174.

77 Truchim, Konfederacja Dzikowska, pp. 127-128.

${ }^{78}$ Cieślak, Stanisław Leszczyński, p. 170.

${ }^{79}$ Ibid., p. 171.
} 
allegiance to him. ${ }^{80}$ When the following day Leszczyński told the council of the Confederations about his actions, its members did not consent to them and even refused to listen to the text of the renunciation act.

After the renunciation of his claim to the Polish throne Leszczyński stayed for some time in Königsberg. In the opinion of the French king Leszczyński's stay in Prussia would come in useful to France as an extra diplomatic measure in the talks in Vienna. The negotiations between France and Austria continued after the first phase of the truce until 18 November 1738, when the final third accord was signed. Only on 5 May 1736 Leszczyński, L'Anglais and a number of Confederates left Königsberg for France via Berlin. ${ }^{81}$

The contemporary political and military expansion of the Russian Empire was directed against the Commonwealth and Turkey. In the Commonwealth a significant achievement was the accession to the throne of Augustus III, dependent on Petersburg. In 1735, exploiting the Turkish lack of success in the war with Persia, Russia started a war against Turkey. Therefore Russia was concerned about concord and the authority and weight of Augustus III in the Commonwealth as well as about his recognition by Western powers. The resolution of the conflict was hindered by the presence of the Confederates in Prussia. Consequently, Augustus III and his advisers sought to return the Confederates to the Commonwealth and to have them well-disposed towards him. Russia, doubtless, supported such plans.

The activities of the Confederates were studied intently by the Russian envoy in Warsaw, Baron Hermann Keyserling. Late in 1734 he proposed a plan on ending the crisis in the Commonwealth. The envoy paid great attention to arbitration. A good beginning could be the Russian tsarina's manifesto, explaining and justifying Russia's policy in the Commonwealth and assuring the withdrawal of Russian troops when peace descended on the country. Such a manifesto was really issued in December 1734. Additionally, Keyserling suggested that the Confederates be drawn to Augustus III's side by money and promises of posts and elderships. ${ }^{82}$

${ }^{80}$ Ibid., p. 173.

${ }^{81}$ Ibid., p. 181.

${ }^{82}$ E. Szklarska, 'Próby pacyfikcji Rzeczpospolitej w latach 1734-1736. Zabiegi o pozyskanie stronników Leszczyńskiego dla obozu Wettyna', Rozcnik Gdański, XLVI, 1986, p. 173. 
Dissolution of the General Confederation of the GDL At the end of 1735 the Russian envoy succeeded in establishing preliminary contacts with the Confederates in Königsberg. In this affair he was assisted by the Russian resident in Königsberg, Gofrat Belk. The Confederates, however, agreed to talk only directly with the representatives of Augustus III. Belk wrote about the Confederates' attitude to Keyserling on 24 December 1735.The Russian envoy immediately informed Augustus III about it, who refused to send his commissars to Königsberg. ${ }^{83}$

In that letter Keyserling wrote to Belk that Augustus III did not recognize the Confederates as a part of the Commonwealth and consequently could not conduct negotiations with them. Such negotiations were not foreseen by the truce accord of Vienna either. Therefore the Russian envoy proposed that the Confederates should be informed about that attitude and convinced to acknowledge Augustus III as their sovereign and come to Warsaw. Keyserling even sent Belk several passports which could be issued to willing Confederates. Besides, Belk was informed that all palatinates and powiats of the Commonwealth had already seceded from the Confederations and had recognized Augustus III. As a legitimate king Augustus was acknowledged by the Pope, too. The Russian resident also had to bring this news to the Confederates. ${ }^{84}$ Belk seems to have informed Keyserling about the request of the marshal of the Confederation M. Oginskis and his son to grant the post of palace marshal of the GDL to the young Oginskis. The Russian envoy expressed his regret about having learned this request too late because it had been granted already to Ignas Zaviša (Ignacy Zawisza). ${ }^{85}$ Judging from this episode the marshal of the Confederation of the GDL perceived that further opposition to Augustus III was senseless and started minding about the matters of his family.

The correspondence between Keyserling and M. Oginskis began early in $1736 .{ }^{86}$ In addition, Belk regularly informed Keyserling about the activity and mood of the Confederates. Thus, the Russian envoy was well aware of the situation and could choose appropriate

${ }^{83}$ H. Keyserling to G. Belk, a copy of the letter of 4 Jan. 1736, Warsaw, AVPRI, f. SRP, op. 79/1, 1736, d. 8, ff. 14-18.

${ }^{84}$ Ibid.

${ }^{85}$ Ibid.

${ }^{86}$ Keyserling to the Empress, report of 19 Jan. 1736, Warsaw, AVPRI, f. SRP, op. $79 / 1,1736$, d. 8 , ff. $47-48$. 
tactical measures. In the middle of January M. Oginskis offered Keyserling his scheme for the solution of the problem of the Confederates of the GDL. ${ }^{87} \mathrm{He}$ requested that Augustus III and the Russian envoy should guarantee individual liberty, honour and inviolability of property for the Confederates, returning to the GDL. He also called for a general amnesty to be announced in the sejm to dismiss the charges against himself as the marshal of the Confederation, the councillors and the regimental officer A.A. Pociejus concerning the finances, foodstuffs and forage requisitioned during the punitive actions, and that those considering themselves victims would not seek revenge. The Russian forces were asked to stop punitive operations in the Confederate estates, and the forces of the Duke M.S. Višnioveckis and the palatine of Novgorodok stopped collecting three talers from each hearth in the GDL. People driven from the devastated and burnt estates had to be returned to their former places of residence. M. Oginskis wanted the estates of Grodno and Mogilev to be suspended from all payments for two years. The leader of the Confederates of the GDL asked Keyserling to get 5,000 gold chervontsy and send the Russian resident Belk in Königsberg a bill of exchange for that sum. That money, in Oginskis' words, was necessary to pay off the debts of the Confederates. The refugees could return to the Commonwealth only after having discharged their obligations to the creditors. The proposals also included a complaint against the Prussian king who prevented the departure of the Confederates from Prussia before the presentation of two tall conscripts. Oginskis asked Belk to apply to General Katt for that matter. If these endeavours failed, in the opinion of the marshal of the Confederates of the GDL, the Prussian king could possibly be persuaded by mediation of the Russian empress and Augustus III. ${ }^{88}$

Keyserling replied that a general amnesty would release the Confederates from any responsibility for their actions during the internal war. Additionally, if peace prevailed, the Russian army would stop conducting punitive actions and it would be withdrawn from the Commonwealth. Keyserling maintained that the empress and Augustus III could not apply to the King of Prussia as long as the Confederates did not recognize Augustus III as their sovereign. ${ }^{89}$

${ }^{87}$ Ibid.

${ }^{88}$ Oginskis' proposals of Jan. 1736 and Keyserling's response to them, Königsberg, Warsaw, ibid., ff. 50-51.

${ }^{89}$ Ibid. 
There then followed an inevitable process of the recognition of Augustus III by the more prominent émigré Confederates. One of the first was Bishop M. Zienkovičius of Vilnius. Early in September 1735 he expressed his disappointment with the French and promised to go back to his country if France did not offer any real aid by the winter. ${ }^{90}$ At the end of 1735 the bishop acknowledged Augustus III as the legitimate ruler and left Königsberg for Vilnius. Besides, the Prussian king did not receive two tall soldiers. ${ }^{91}$ Possibly that is why in January 1736 Katt invited the Bishop to return to Königsberg allegedly for talks with other noblemen and even sent him a passport. Keyserling, considering that the Prussians intended again to bring the Bishop over to the Confederates, did not approve of his possible return to Königsberg. ${ }^{92}$

The Polish Confederates also started negotiations with the Russian envoy. A leader of the Confederation of Dzików, the palatine of Lublin J. Tarło, invited Keyserling to a meeting at the border with Prussia in January 1736. The palatine wrote about his wish to see peace and order in the Commonwealth. Keyserling declined the invitation, but he persuaded the palatine of Mazovia, Stanisław Poniatowski, to go instead. ${ }^{93}$ Poniatowski met J. Tarło, ${ }^{94}$ and their meeting significantly changed the stance of the Confederates in Königsberg. The palatine of Lublin informed Keyserling about his wish to go to Warsaw and asked for passports and safety guarantees. ${ }^{95}$ Keyserling notified Augustus III about it immediately and sent Belk the passports for the palatine of Lublin. ${ }^{96}$ Promising to go to Warsaw, A.A. Pociejus also asked Keyserling for a passport and safety guarantees. ${ }^{97}$

${ }^{90} \mathrm{Ks}$. bp wileński, wojewoda wotyński, wojewoda belski similiter już się tu z tym sonora voce klaryguja, jeżeli od Francji przed zimq co pomyślnego in rem iuste causae nie stanie się, wszyscy do Warszawy pospiesza salwujac fortuny swoje a nie majac tu o czym dalszego tak uprzykrzonego prowadzić życia - F. M. Ossoliński to J.A. Załuski, letter of 9 Sept. 1735, Königsberg, Korespondencja Józefa Andrzeja Zaluskiego, pp. 452-453.

${ }^{91}$ Keyserling to the tsarina, account of 19 Oct. 1736, Warsaw, AVPRI, f. SRP, op. 79/1, 1736, d. 8, ff. 34-37.

92 Ibid.

${ }^{93}$ Ibid.

${ }^{94}$ Poniatowski to Keyserling, a copy of a letter of Jan. (no date) 1736, s. 1., ibid., ff. 66-70.

${ }^{95}$ Keyserling to the empress, account of 23 Jan. 1736, Warsaw, ibid., ff. 58-60.

${ }^{96}$ Ibid.

${ }^{97}$ Pociejus to Keyserling, a copy of the letter of 26 Jan. 1736, Königsberg, ibid., f. 100. 
On 1 February the son the palatine of Vitebsk T. Oginskis arrived at Warsaw. He informed the Russian envoy that his father and other Lithuanians, staying in Königsberg, were inclined to go to Warsaw if only they managed to free themselves from Prussia. Money was necessary for that. ${ }^{98}$ Keyserling looked to it that the requested 5,000 gold chervontsy be granted by Augustus III. The king, however, did not want to do that himself and he asked the Russian envoy to be an intermediary in this matter. He wanted the Confederates to think that the money came from Russia rather than from $\operatorname{him} .{ }^{99}$

Keyserling sent the palatine of Vitebsk in Königsberg a project of the act of the recognition of Augustus III and an instruction to Belk. ${ }^{100}$ However, he soon learnt about the doubts of M. Oginskis and other GDL Confederates and about their refusal to sign the act acknowledging Augustus III as their ruler. ${ }^{101}$ Oginskis and other Lithuanian Confederates doubted the good intentions and security guarantees, granted by the Russian envoy. They feared that the general amnesty would not protect them from the revenge of those who had suffered from them. Besides, their suspicions were further fuelled by the fact that a similar project of the act on Augustus III's recognition was not sent to the Polish Confederates. The Confederates of the GDL decided that they needed first to consult their counterparts in the Confederation of Dzików. ${ }^{102}$

Keyserling again had to assure the Confederates of his good intentions and wish to bring peace to the Commonwealth. He repeatedly guaranteed the security of those who would sign the act of Augustus III's recognition and would return to the Commonwealth. He stated that the common amnesty to be adopted at the sejm would protect former Confederates not only in Warsaw, but also at home and everywhere else. The Russian envoy said that he did not send a project of the recognition act to the Poles because he was not in

${ }^{98}$ Keyserling to the tsarina, account of 3 Feb. 1736, Warsaw, ibid., ff. 103-104.

${ }^{99}$ The minutes of the conference of the Austrian envoy in Warsaw Karl Franz Mitrowitz Wratislaw, the Russian envoy Keyserling and the ministers of Augustus III Henryk Brül and Józef Aleksander Sułkowski in the castle of Warsaw on 21 Jan. 1736, ibid., ff. 76-79.

${ }^{100}$ Keyserling to the tsarina, account of 19 Feb. 1736, Warsaw, ibid., f. 125.

${ }^{101}$ Keyserling to Belk, a copy of the letter of 19 Feb. 1736, Warsaw, ibid., ff. $128-131$.

${ }^{102}$ Keyserling to Oginskis, a copy of the letter of 19 Feb. 1736, Warsaw, ibid., ff. $128-131$. 
correspondence with the Poles - the Confederates of Dzików. Neither did he send them passports for the same reason. Keyserling commented that the Confederates of the GDL needed not to consult with the Confederates of Dzików because the Lithuanians and the Poles shared the same rights and liberties. He stressed that the Lithuanians had formed their own independent confederation and, to his knowledge, the two confederations were not interlinked. In the opinion of the Russian envoy, the Lithuanians, having created their confederation separately, could dissolve it on their own as well. ${ }^{103}$ Keyserling again sent a copy of the same recognition act expressing his conviction that this time M. Oginskis would sign it, and that would be followed by other Lithuanians. ${ }^{104}$

Keyserling sent Belk a bill of exchange for 4,400 gold chervontsy. That sum had to be paid by the Königsberg merchant Kade and passed over to the palatine of Vitebsk. Keyserling suggested that from that sum M. Oginskis should give 400 to the deputy starosta of Upyte், Kazimieras Straševičius (Kazimierz Straszewicz), who took the initiative in encouraging other GDL Confederates to acknowledge Augustus III as ruler. The rest of the sum could be distributed by the palatine of Vitebsk at his discretion. The Russian envoy emphasized that he fulfilled his promise of 5,000 chervontsy - he had given 600 to M. Oginskis' son when he had come to Königsberg from Warsaw. Belk was authorized to encourage M. Oginskis to leave for Warsaw without delay. In case of complications concerning the two promised tall soldiers, Keyserling suggested that M. Oginskis might leave his wife or son as hostages. The problem of hostage release could be solved following his arrival at Warsaw. ${ }^{105}$

By that time the tendency to capitulation among the Polish Confederates had become obvious. Keyserling passed a similar project of the act of the recognition of Augustus III to the Confederation of Dzików through the palatine of Lublin who came to him in Warsaw at the end of February 1736. ${ }^{106}$ The envoy informed the empress that he asked Augustus III to give 5,000 chervontsy to the Poles as well - a sum equal to that which he had given to the

103 Ibid.

${ }^{104}$ Ibid.

${ }^{105}$ Keyserling to Belk, copy of the letter of 19 Feb. 1736, Warsaw, ibid., ff. $128-131$.

${ }^{106}$ Keyserling to the tsarina, account of 21 Feb. 1736, Warsaw, ibid., f. 138. 
Lithuanians. ${ }^{107}$ Augustus III agreed to give the money to the Confederates of Dzików, he only asked Keyserling to hand it in after his recognition. ${ }^{108}$ Hitherto historians have maintained that the Russian envoy ransomed some of the indebted noblemen in Prussia by Russian money and thus made them pro-Russian. ${ }^{109}$ Now it can be stated quite unquestionably that the Russian envoy was more economical and that it was Augustus III who paid the debts of his former enemies without, however, letting them know about it. And the former assumption remains valid: many of the ransomed noblemen, considering that they should be thankful for that service to Russia, consequently became loyal to the empire.

The texts of the recognition of the Lithuanian and Polish Confederates were analogous. Their marshals had (1) to declare that they recognized Augustus III as ruler; (2) to confirm that Leszczyński freed the Confederates from all their previous obligations to him by a universal charter; and (3) to promise to go to Warsaw. The recognition act also comprised Augustus III's commitment to confirm all former rights and freedoms of the nobles and the posts held by them before the Confederation. The pledge of the allied states with regard to the rights and freedoms of the nobles was dealt with in the text. Other assurances of Augustus III (to convene a pacification sejm and to propose that the sejm should declare a general amnesty) were indicated, too. ${ }^{110}$ Thus, the recognition act recorded the earlier commitments of both sides.

The return of Jan Sołłohub, the treasurer of the GDL, encouraged other Confederates to come back to the Commonwealth. He arrived to Warsaw from Königsberg on 7 February 1736 and was honoured by an audience with Augustus III. ${ }^{111}$ The GDL treasurer had not belonged to the Confederates. He came to Prussia for fear of his life already in 1733, before Leszczyński's election. The invading Russian army detained his wife, and he emigrated in order not to suffer the same fate. The administration of the GDL treasury was entrusted by Augustus III to his adherent the palatine of Trakai Juozapas Oginskis (Józef Ogiński). Following Sołłohub’s

${ }^{107}$ Keyserling to the tsarina, account of 29 Feb. 1736, Warsaw, ibid., ff. 160-163. 108 Ibid.

${ }^{109}$ Staszewski, 'Emigracja polska', p. 162; Achremczyk, 'Emigranci polscy', p. 198.

${ }^{110}$ A copy of the recognition act, AVPRI, f. SRP, op. 79/1, 1736, d. 8, f. 164.

${ }^{111}$ Keyserling to the tsarina, account of 11 Feb. 1736, Warsaw, ibid., ff. 110-111. 
return the control of the treasury was assigned again to him. Thus, the Confederates of the GDL could ascertain that Augustus III was willing to restore the political refugees in their former official posts.

On 12 March 1736 the marshal of the Confederation of the GDL the palatine of Vitebsk M. Oginskis came back to Warsaw from Königsberg. ${ }^{112}$ He brought the act of the recognition of Augustus III, which was signed by the Lithuanians. Consequently, the General Confederation of the GDL ceased to exist. Actually the signing of the act in Königsberg was not quite smooth. Five Confederates refused to put their signatures; among them there were two prominent members - the strazinik of the GDL A. A. Pociejus and the notary of the GDL M.J. Masalskis. They recognized Augustus III as ruler together with the Confederates of Dzików at the end of March 1736. ${ }^{113}$

The Pacification Sejm was held in Warsaw between 25 June and 9 July 1736. It announced a general amnesty. ${ }^{114}$ During the last session on 9 May the election act of Augustus III was adopted. It was signed by the majority of the senators and representatives having participated in the sejm. ${ }^{115}$ Among them there were the most prominent Confederates of the GDL: Bishop M. Zienkovičius of Vilnius, the palatine of Vitebsk M. Oginskis, the strazinik of the GDL A. A. Pociejus, the notary of the GDL M. J. Masalskis, and others. ${ }^{116}$

It is worth noting that historical sources actually contain very few documents relating to the General Confederation of the GDL. Augustus III's followers probably took care to destroy them. Such a conclusion could be drawn on the basis of the requirements of the Lithuanian members at the Pacification Sejm to destroy not only the documents of the General Confederation of the GDL, but also those of the Confederation of Dzików. The instruction adopted at the Ukmerge powiat dietine on 14 May 1736 authorized its representatives at the Pacification Sejm the starosta of Vabalninkas Mykolas Antonevičius (Michał Antoniewicz) and the equerry of Ukmergè powiat Aleksandras Micevičius (Aleksander Micewicz) to require the destruction of the documents of both Vilnius and

112 Keyserling to the tsarina, account of 13 March 1736, Warsaw, ibid., f. 176.

${ }^{113}$ Keyserling to the tsarina, account of 2 Apr. 1736, Warsaw, ibid., d. 9, ff. $16-17$.

114 Volumina legum, vol. 6, St Petersburg, pp. 318-319.

115 Ibid., pp. 315-318.

${ }^{116}$ Ibid. 
Dzików Confederations as equally deleterious for society. ${ }^{117}$ A similar requirement is found in the instruction of the dietine of the Upyte powiat of 14 May 1736. The delegates to the Pacification Sejm - the Upyte deputy starosta K. Straševičius (incidentally, a former Confederate) and the Obeliai starosta Grotthus - were instructed to demand the destruction of all documents of the Confederation of the GDL, bearing the signatures and seals of Vitebsk palatine M. Oginskis and the strażnik of the GDL A. A. Pociejus. ${ }^{118}$

$* * *$

The aim of the General Confederation of the GDL, formed in accordance with the tradition of noble democracy in Vilnius on 5 April 1734, was political - to defend the right of the elected king Leszczyński to the throne. Safeguarding the political self-determination of the nation, the General Confederation of the GDL drew on the legitimacy of the democracy of nobles - one of the most deeprooted traits of the mentality and political culture of the nobility. The defeat, suffered at the hands of the more powerful enemies - the united forces of the adherents of Augustus III, the Russian army and the Saxon forces, which invaded the Kingdom of Poland - left an indelible imprint on the consciousness of the nobles. Hostility to the king, who had been imposed by force, and his proponents produced new forms of resistance, among them the confrontation to the projects of reforms and laws proposed by political opponents. The manifestation of that strategy was the fact that the pacification sejm was the only one to end successfully throughout the entire reign of Augustus III.

The rule of Augustus III was also complicated by various financial and other kinds of ties between many influential noblemen, participants of the General Confederations of the GDL and Dzików having resided for a long period in the political emigration in East Prussia, and hundreds of nobles who had passed some time there, on the one hand, and the Prussian Kingdom, extremely unfavourable to Saxony and the reforms of the Commonwealth. ${ }^{119}$ Quite a number of the former Confederates continued to maintain confidential contacts with France. For example, on the intercession of Leszczyński,

${ }^{118}$ A copy of the Upyte powiat dietine instruction to the delegates to the sejm, AVPRI, f. SRP, op. 79/1, 1736, d. 8, ff. 345-349.

${ }^{119}$ Staszewski, 'Emigracja polska', p. 162. 
the marshal of the GDL General Confederation was granted a pension by France since the middle of 1738 . Subsequently Versailles guaranteed him an annual pension of 6,000 livres for life. ${ }^{120}$

By creating the GDL General Confederation and taking part in the battles against the interventionist forces, Lithuanian nobles endeavoured to preserve the sovereignty of the Commonwealth and protect the country from Russian influence. Thousands of nobles risked their lives and the security of their lands to join the armed resistance movement against the interventionists and adherents of Augustus III. Despite the fact that some tried to avoid supporting the confederate army financially or joining it, many nobles did support the army either financially or joined it personally and presented peasant conscripts from their estates. The total number of the forces on the confederate side must have reached around 10,000. Despite these efforts, the battle was lost. The disaster was great, and the devastation of the country weakened the confidence of the nobles to defend the Commonwealth from the aggression of the neighbouring states and encouraged the spread of the pacifist ideas. Such attitudes were characteristic for the entire period of Augustus III's reign.

The presence of the Russian interventionist army was crucial for imposing Augustus III, who was supported by a minority, upon the gentry of the Commonwealth. Russian forces crushed the resistance of the Confederations of both Dzików and the GDL in 1734-1735. Meanwhile Russian diplomats were particularly active in the negotiations on the dissolution of the two Confederations. In the course of time this kind of practice became commonplace: combining military and diplomatic measures Russia backed up submissive rulers, mediated in the conflicts between the king's court and the opposition and guaranteed the security of the opposition leaders who had formerly acted against the king. Russian influence, undercut at the end of Augustus II's rule, became increasingly apparent, and the Commonwealth was again brought within the orbit of its eastern neighbour. Thus began the process of the subordination of the Commonwealth, its king's court and political groupings on Russia, which in future were to develop into a protectorate.

${ }^{120}$ Cieślak, Stanisław Leszczyński, p. 161-162. 
The history of the General Confederation of the GDL marks a certain stage of the political culture of the Lithuanian gentry. It was the last confederation of the entire GDL which was not allied with the politically close Polish Confederation of Dzików in a common confederation, covering the whole Commonwealth. All subsequent confederations at one time or another entered into a formal common union, attesting confederation ties between the GDL and Poland. Confederations, formed in the sejm 'from above', were common from the very beginning. The 'Czartoryski' Confederations of 1764 1766 officially were also united. The 'Commonwealth' Confederations of Radom, Bar and Targowica were amalgamated, too. The two latter confederations attached much significance to the formal act of integration: the union of the Confederations was announced at the Confederate meeting in Biała between 27 October and 7 November 1769; and the union of the Confederation of Targowica and the General Confederation of the GDL of 1792 at the meeting in Brest on 11 September 1792. The fact that the democratic confederations of the GDL and Poland which functioned between 1734 and 1736 did not unite was no pure coincidence. The leadership of the Confederation of Dzików proposed the formation of a union, and there were conditions for such integration. However, some reluctance on the part of the leaders of the General Confederation of the GDL prevented that move.

Translation: Alfonsas Laučka

Author Details

Docent Feliksas Sliesoriūnas researches the political history of the GDL of the early 18 th cent., socio-political processes of the first half of the 19th cent. in Lithuania and the history of the Pedagogical University of Vilnius.

Address: Lietuvos istorijos institutas, Kražių 5, 01108 Vilnius, Lithuania

Email: slies@centras.lt 


\section{LIETUVOS DIDŽIOSIOS KUNIGAIKŠTYSTĖS GENERALINE் KONFEDERACIJA 1734-1736 M.}

\section{Santrauka}

\section{FELIKSAS SLIESORIŪNAS}

Po karaliaus Augusto II mirties 1733 m. prasidejjusio tarpuvaldžio metu Lenkijos-Lietuvos valstybejje vyko kova tarp dviejų pretendentu - mirusio karaliaus sūnaus Saksonijos kurfiursto Frydricho Augusto ir ilgą laiką emigracijoje Prancūzijoje gyvenusio Stanislovo Leščinskio (Leszczyński) - šalininkų. Elekciniame seime 1733 m. rugsèjo 12 d. karaliumi buvo išrinktas S. Leščinskis. Tačiau Saksonijos kurfiursto šalininkai su tuo nesusitaikè ir remiami ịsiveržusios į Respubliką) Rusijos kariuomenès spalio 5 d. karaliumi paskelbè Frydrichą Augustą - Augustą III. Respublikoje prasidèjo vidaus karas, kurio metu lemiamą vaidmeni, palaužiant S. Leščinskio šalininkų pasipriešinima, suvaidino intervencinès Rusijos ir Saksonijos kariuomenès. Vidaus karo metu S. Leščinskio šalininkai Lietuvos Didžiojoje Kunigaikštystēje (toliau - LDK) $1734 \mathrm{~m}$. balandžio 5 d. Vilniuje demokratiniu būdu, remdamiesi vaivadijų ir pavietų konfederacijomis, sukūrẻ LDK generalinę konfederaciją. Tai buvo prisiekusios bajorijos sajunga, susivienijusi ginkluotai kovai prieš Rusijos intervencinę kariuomenę ir Augustą III, kurį konfederatai paskelbė sosto uzurpatoriumi. Bendros LDK konfederatų karinès pajègos siekè 8-10 tūkst. karių, kurias sudarẻ S. Leščinskiui lojali LDK reguliarios kariuomenès dalis, į konfederatų kariuomenę stoję bajorai bei jų surinkti valstiečiai rekrūtai. Tačiau šiu jègų nepakako ir konfederatų kariuomenè patyrè pralaimèjimą. $1734 \mathrm{~m}$. pabaigoje didžioji jos dalis paliko LDK teritoriją ir susitelkè Lenkijos Karalystei priklausiusioje Mazovijos vaivadijos šiaurinèje dalyje bei Varmijoje, kur tikejjosi sulaukti pagalbos iš emigracijoje Rytų Prūsijoje (Karaliaučiuje) issikūrusio S. Leščinskio. Tačiau rusų kariuomenei puolant ir ten, daugelis LDK konfederatų taip pat pasitraukè ị Rytų Prūsiją, o kiti išsiskirstė. Paskutinis LDK konfederatų karinis dalinys nutraukẻ kovą $1735 \mathrm{~m}$. gegužès mėnesi. Emigracijoje Karaliaučiuje LDK konfederacijos vadovybè tęsè savo politinę veiklą iki 1736 m. pradžios. Politiškai artima LDK generalinei konfederacijai buvo Lenkijos Karalystès generalinè konfederacija, pagal savo ịkūrimo vietą dar vadinta Dzikovo konfederacijos vardu. Lenkai siūlè abiems konfederacijoms susivienyti ị bendrą konfederaciją, tačiau LDK konfederatų vadovybè to nenorejjo. $1734 \mathrm{~m}$. ikurtoji LDK generalinė konfederacija buvo paskutiné tokio tipo LDK bajorijos sajunga, kuri nesusijungė su politiškai gimininga Lenkijos Karalystès generaline konfederacija. Tačiau abi konfederacijos emigracijoje glaudžiai bendradarbiavo. Po S. Leščinskio abdikacijos 1736 m. sausio 27 d., kurią paskatino Prancūzija, prasidèjo intensyvios LDK konfederacijos vadovybės derybos su Rusijos pasiuntiniu Varšuvoje H. Keyserlingu. Buvo suderintos LDK konfederacijos paleidimo sąlygos. LDK konfederatų vadams prašant, Rusijos pasiuntinys suteikè 5000 červoncų (dukatu), kad emigrantai galètų apmokèti savo skolas Prūsijoje. Šiuos pinigus Rusijos pasiuntinys gavo iš Augusto III, tačiau karalius norèjo, kad emigrantai galvotų, jog pinigus gauna iš Rusijos. Prieš paleisdami LDK konfederaciją jos vadovai ketino suderintį ši savo sprendimą su Lenkijos generalinès konfederacijos vadovybe, bet itikinèjant Rusijos pasiuntiniui, sprendimą prièmė savarankiškai. LDK konfederacija buvo paleista $1736 \mathrm{~m}$. kovo pabaigoje. Tik buvę LDK konfederatų kariuomenès vadai - regimentorius A. A. Pociejus ir M. J. Masalskis atsisakè tada pripažinti Augustą III. Tai jie padarẻ kartu su Lenkijos konfederatais $1736 \mathrm{~m}$. kovo pabaigoje. Lenkijos konfederatams Rusijos pasiuntinys 
išrūpino iš Augusto III analogišką 5000 červoncų sumą. 1733-1736 m. vidaus konfliktus galutinai užbaigė $1736 \mathrm{~m}$. birželio-liepos mėnesiais posèdžiavęs pacifikacinis seimas, amnestavęs konfederatus ir patvirtinęs Augusto III elekciją. Kovų metu buvo labai nualintas kraštas, daugelis buvusių konfederatų susisaistė įvairiais įsipareigojimais su Augustui III ir Respublikos reformoms priešiška Prūsija, Prancūzija. Pati valstybė pateko Rusijos priklausomybèn. Visa tai apsunkino Augusto III valdymą. 